\title{
A Theory of Diversification and Cross-subsidy for Eurobonds
}

Philipp J. M. Loick

Supervisor: Drs. Gaby Contreras 


\begin{abstract}
In the face of excessive yield spreads on sovereign bonds in the European Monetary Union, the issuance of joint debt commonly known as Eurobonds has been proposed to ease the access to credit for fiscally struggling countries. This paper is the first to consider Eurobonds in terms of diversification and cross-subsidy benefits. It shows that the risk-sharing nature of Eurobonds lowers sovereign default probability in a non-replicable way for investors thereby lowering investment losses on a macro-level. Countries benefit as well from lower default probability that prevents sovereign bankruptcy costs. On a micro-level, fiscally strong countries have to weigh the benefits of Eurobonds against the two-fold costs of higher interest payments and financial support for defaulting countries. With further research, the argument brought forward in this paper will contribute to a more comprehensive debate about the benefits and costs of Eurobonds.
\end{abstract}




\section{Introduction}

In recent years, The European Monetary Union (EMU) has been hit by the most severe crisis in the young history of the common currency, the Euro. This crisis has been evoked by the inability of several EMU member states to honor interest obligation and refinance their sovereign debt. The struggle has fueled expectations on the financial markets about debt haircuts in the affected countries. Interest rates raised significantly, putting even more difficulties on countries to refinance their debt. In the discussion about ways to solve the solvency and liquidity problems of these member states namely Greece, Cyprus, Italy and Spain leading politicians proposed issuing joint debt in the Eurozone. This joint debt would come in the form of joint bonds issued and backed by all EMU member states. In the political debate, these bonds have become known as Eurobonds. In the view of the proponents, Eurobonds reduce the interest rate burden of struggling member states and ensure continuous access to financial markets even in crisis times. Several Euro member states have expressed their concerns for such a measure particularly fiscally strong economies like Germany and the Netherlands. Apart from potential moral hazard problems, interest rate considerations play the largest role in the resistance of these countries. In an influential article, the German economist Kai Carstensen (2011) from the ifoinstitute estimates that joint EMU debt would heavily increase the interest rates for fiscally solid countries as their low risk is pooled with the higher risk of countries at the brink of defaulting. As one of the first economist, he provided financial estimations for the costs that Germany and other countries would bear in the presence of Eurobonds. Specifically, he argued that the interest rate of joint Euro bonds would be the weighted average of the individual countries' rates resulting in additional interest costs of $€ 47$ billion for Germany. Several scholars entered the debate and provided their opinion on the effect that joint bonds will have on interest rates via liquidity gains (Delpla \& von Weizsaecker, 2011) and contagion prevention (Favero \& Missale, 2011). However, an important argument has been neglected in the debate so far, namely the impact that Eurobonds will have on interest rates via fundamentals. In this paper, I will develop a theory of diversification and cross-subsidy demonstrating that a fiscal network established by Eurobonds exhibits a lower probability of default and leads to less investors' losses. As these benefits cannot be replicated by individual investors, Eurobonds create value and investors will demand lower credit premiums on sovereign debt. In contrast to Carstensen et al. (2011), I therefore predict that Eurobonds will have lower interest rates than the weighted average of the interest rates on national bonds. 
This paper will proceed in four steps. First, I will trace the development of the European sovereign debt crisis and analyze the Eurobond proposal as a proposed solution to this crisis. As the Eurobond debate is centered around its impact on interest rates, I will identify the determinants for yield spreads differentials and conduct a literature review on the predicted impact of Eurobonds on interest rates. Second, I will develop a theory of diversification and cross-subsidy for Eurobonds. I will describe how Eurobonds lower the probability of sovereign default for member states in a non-replicable way for investors. Third, I will establish a formal mathematical proof for the argument put forward in the theory. For this purpose, I will consider a theoretical $\mathrm{N}$ country model and compare default probability of countries in fiscal autarky with countries engaged in a fiscal network. Fourth, I will conduct simulations using this theory and perform sensitivity analyses for the basic insights against changes in assumptions.

\section{Literature Review}

\subsection{Causes of the European Sovereign Debt Crisis}

In the aftermath of the financial crisis, countries of the European monetary union have faced difficulties refinancing their public debt and serve interest payments. Particularly, Greece, Italy, Spain, Portugal and recently Cyprus have been exposed to substantial yield spreads on government bonds since late 2009 due to investors' doubt in the ability to repay sovereign debt. This period of persisting problems to roll over debt and ensuring liquidity is referred to as the "European sovereign debt crisis" (Lane, 2012).

The emergence of this crisis has been ascribed to a sharp increase in both sovereign debt (Lane, 2012) and private sector debt (Fagan \& Gaspar, 2007) as well as a dispersion of current account imbalances within the Eurozone in the last decade (Herrmann \& Jochem, 2005; Arghyrou \& Chortareas, 2006; Blanchard \& Giavazzi, 2002).

Concerning public debt, the Maastricht Treaty stipulated a maximum deficit level of $3 \%$ of GDP per year and $60 \%$ of GDP for accumulated total sovereign debt. Since the adoption of the treaty in 1990, several countries have systematically contravened these targets and accumulated massive amounts of debt. Italy's and Greece's debt/GDP ratio increased from above $90 \%$ in 1990 to more than $150 \%$ and $120 \%$ today respectively. This high amount of public debt has cast doubt on the investor side on the ability of these countries to repay their debt (Lane, 2012). Particularly, the financial crisis preceding the European sovereign-debt crisis led countries to construct bailout packages that inflated budget deficits and debt ratios 
(Lane, 2012).

Moreover, a comparable increase in private sector debt is observable in this period. Whereas Greece had a private debt/GDP ratio of $34.8 \%$ in 1998 , this ratio stood at $84.4 \%$ in 2007 . Italy's private debt/GDP ratio rose in the time period from $81.2 \%$ to $184.3 \%$. This development was the result of lower interest rates and easier access to credit which stimulated borrowing for consumption and property purposes. Such private debt often becomes public debt after banking crises and poses additional challenges on a country's fiscal position (Reinhart \& Rogoff, 2010).

Moreover, since its inception the European monetary union has been characterized by widening current account imbalances. Whereas countries like Germany exhibited significant current account surpluses $5.7 \%$ of GDP for Germany between 2008 and 2011 -, Greece, Portugal and Spain had huge current account deficits of $11.1 \%, 10.5 \%$ and $5.8 \%$ respectively. Several explanations have been brought forward. Herrmann and Jochem (2005) argue that deteriorating current account balances were caused by the corresponding increase in public debt, whereas according to Blanchard and Giavazzi (2002), higher growth prospects in these countries triggered lower private savings and higher foreign investment. Arghyrou and Chortareas (2006) ascribe the imbalances to the common currency in the EMU. The introduction of the Euro led to the formation of a currency union in which all exchange rates are pegged to each other. This unification of exchange rates led to a real exchange rate appreciation for economically weaker countries like Greece, Spain and Portugal and a real exchange rate depreciation for countries like Germany thereby prompting current account imbalances.

In the aftermath of the global financial crisis 2008, investors reassessed growth prospects and fundamentals of countries, particularly those with macroeconomic imbalances (Lane, 2012). Moreover, the time period starting 2008 was characterized by a massive repatriation of funds which previously had been invested in high growth prospect countries (Milesi-Ferretti \& Tille, 2010). These aspects worsened the economic situation in Southern European countries that had already been severely affected by the financial crisis. The actual sovereign debt crisis was then triggered by higher than expected deficit announcements in Ireland, Spain and Greece. The declared deficit of $12.7 \%$ of GDP in Greece cast doubt with investors on the country's ability to pay back its debt.

The reluctance of investors to invest in sovereign bonds of struggling countries led to a sharp increase in yield spreads over German Bunds. Yields on 10-year bonds diverged by more than 1200 basis points from German Bunds for Greece, 800 basis points for Portugal and Ireland and 350 basis points for Italy in 2011 (Figure 1). A similar development could be observed 


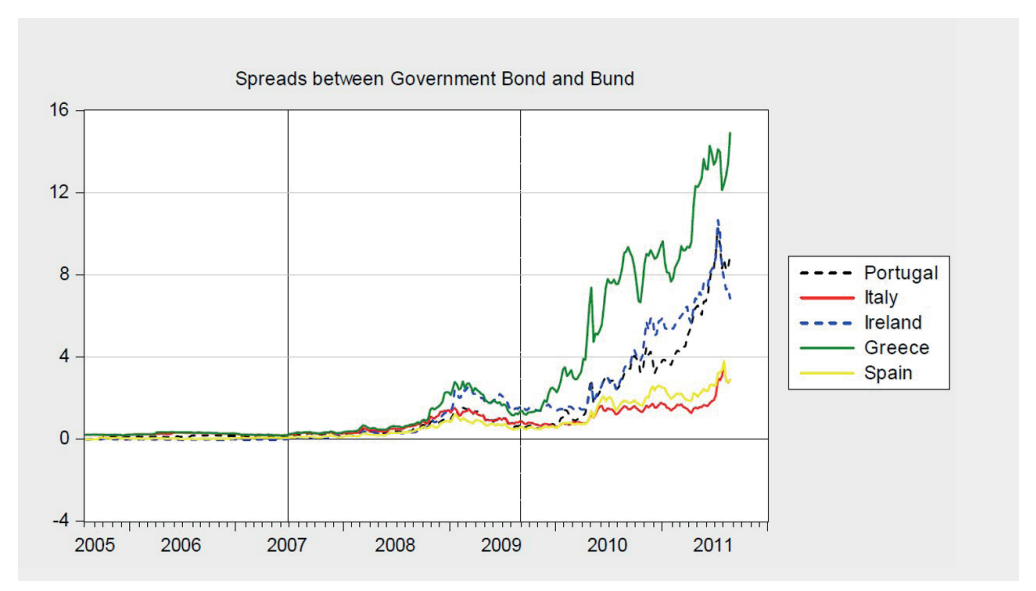

Figure 1: Sovereign bond yield spreads over German Bunds Source: Favero \& Missale (2011)

for credit default swaps which rose 25 -fold in value at the peak of the Greece sovereign debt crisis. These higher interest rates made it even more difficult for countries like Greece to refinance their debt and serve interest payments. These difficulties have placed Greece and other countries at the edge of sovereign bankruptcy.

\subsection{The Eurobond Proposal}

One of the most prominent suggestions on how to tackle this sharp yield spread increase and enable countries to refinance their debt at reasonable interest rates is the introduction of Eurobonds. Eurobonds are defined as sovereign debt bonds issued jointly by the European Monetary Union and backed jointly and severally by member states (Torgersen, 2012), so that member states would depending on the structure finance part or their entire debt jointly with other member states. One single interest rate will be paid by all countries. Joint and several guarantee stipulates that each issuer guarantees the totality of the obligations of the common instrument, making it an indivisible legal object (Favero \& Missale, 2011). Consequently, investors have legal recourse to all participating issuers if the obligations of one country are not met. The bonds would be issued by an independent euro debt agency like a newly created EMU fund (Favero \& Missale, 2011) or an Independent Stability Council (la Dehesa, 2011).

Two distinct benefits of Eurobonds have been presented in the current 
literature. First, Favero and Missale (2011) and la Dehesa (2011) consider Eurobonds as an effective way to solve the current European sovereign debt crisis. More specifically, they argue that joint debt would enable all participating countries to borrow at one interest rate. With fiscally strong countries like Germany, this common interest rate is assumed to be in between the current yields for German bunds on the one hand and fiscally struggling countries like Greece. Therefore, Eurobonds would help struggling countries to refinance their debt at lower rates than the yield demanded on their national bonds. Similarly, Eurobonds would be a signal to investors of stronger fiscal and political union restoring investor's confidence in the repayment of government debt (la Dehesa, 2011). Second, the Euro currency could become a second international reserve currency with the help of Eurobonds due to the volume of a unified sovereign debt market (la Dehesa, 2011). The benefits of being a reserve currency are two-fold. On the one hand, possessing an international reserve currency is generally associated with political and economic power (Chinn \& Frankel, 2005). On the other hand, the status of a reserve currency inflates the demand for a currency and thereby increases liquidity in markets denominated in this currency. This higher liquidity gives investors security that they are able to sell and buy bonds at fair market prices. A lower liquidity premium will therefore be required, thereby lowering interest rates for countries whose national bonds currently suffer from illiquidity (Favero \& Missale, 2011).

However, critiques have identified drawbacks and challenges with the introduction of Eurobonds. The first revolves around the united interest rate. While fiscally struggling countries would benefit from Eurobonds in terms of lower interest rates, fiscally strong countries would have to accept higher yields on their national debt. A re-distributive scheme would have to be set in place to motivate fiscally strong countries to join Eurobonds. Several proposals have been made for such a scheme (Muellbauer, 2011; Hild, Herz, \& Bauer, 2011; Grauwe \& Moesen, 2009). However, a redistributive scheme with fiscally weaker countries bearing disproportional interest payments would diminish the benefits Eurobonds are designed to offer to them. In the absence of any value created by Eurobonds, those with a redistributive scheme would carry the same interest rates as national bonds for each participating member states.

The second challenge of Eurobonds concerns moral hazard. Due to the joint guarantee, countries can be assured that other member states meet their debt obligation in case they are unable to do so (Prinz \& Beck, 2012). This situation creates incentives for member states to decrease primary surpluses used to pay interest by either decreasing tax revenue or increasing government expenditure. However, this problem is not inherent to the idea 
of Eurobonds and can be solved with an effective structure in place. For instance, Delpla and von Weizsaecker (2011) suggest to split national debt into a blue and red tranche. The blue tranche would be issued in the form of Eurobonds jointly and severally backed by member states and cover debt according to the Maastricht treaty up to $60 \%$ of GDP. All debt in excess of this value would be issued as red bonds by the country individually.

Lastly, critiques quote the no-bailout clause which puts legal restrictions on Eurobonds. According to article 125.1 of the Treaty on the Functioning of the European Union, assuming financial commitments of other Member States is prohibited. A jointly guaranteed Eurobond would require countries to assume financial commitment in the case of another country's default. On a related operational note, Eurobonds would pose significant costs of complexity and inflexibitity on the European monetary union (Favero \& Missale, 2011) and require a harmonization of fiscal policy (la Dehesa, 2011).

When considering the benefits and drawbacks of Eurobonds, the central issue in the Eurobonds debate revolves around the interest rate investors would require for investing into Eurobonds and thus the question whether Eurobonds could create value for investors. As Favero and Missale (2011) put it, "the incentive for participation to common issuance depends [] among others on the borrowing costs [of participating member states]". The political dimension of a second reserve currency and the operational, legal and moral hazard issues largely depend on the configuration of Eurobonds. These aspects do not directly relate to the key issue that Eurobonds are supposed to tackle, namely the yield spreads for struggling countries. The key question in evaluating Eurobonds is therefore:

Which impact do Eurobonds have on the interest rate paid by participating countries compared to national bonds?

An analysis of this question requires understanding of the determinants of sovereign bond yield spreads. These determinants constitute the channels through which Eurobonds can have beneficial effects on the country's interest rate.

\subsection{The determinants of sovereign yield spreads}

Three major determinants of interest rate yield spreads have been identified in economic research: 1. Credit Risk 2. Liquidity Risk and 3. Psychologic Factors.

The first determinant relates interest rates on sovereign bonds to the underlying macroeconomic fundamentals of a country. Credit risk then refers 
to the risk that a country is unable to honor its interest obligations and repay its debt at maturity (Favero \& Missale, 2010). Factors like deficit-to-GDP, debt-to-GDP and GDP growth (Dewachter, lania, Lyrio, \& de Sola Perea, 2013) are used for this analysis. In a fundamental model, Hull, Predescu, and White (2012) relate nominal interest rates to the real interest rate, the probability of default of a country and the expected loss given default. This model will be adopted in this paper. Barrios, Iversen, Lewandowska, and Setzer (2009) distinguish fundamentals into international and domestic factors. They show that during times of financial distress, domestic factors measured by fiscal conditions and current account balances become more important in explaining yield spreads. Generally, fundamentals accurately predict the level of interest rate for sovereign bonds (Amira, 2004; Eichengreen \& Portes, 1985; Yue, 2010)

Second, liquidity of the sovereign bond market impacts yield spreads. Liquidity risk refers to the risk that an asset of a particular instrument cannot be sold at its theoretical price (Hull, 2011). Given insufficient liquidity in a market, an investor will require a liquidity premium for accepting this risk (Favero \& Missale, 2011). Low liquidity is generally associated with high transaction costs posing additional costs on investors. Dewachter et al. (2013) show that particularly during the time preceding the European sovereign debt crisis, liquidity was a major determinant of yield spreads, becoming less important during the crisis.

Lastly, investor's sentiment influences yield spreads. Giordano, Linciano, and Soccorso (2012) show that Spain and Italy had excess yield spreads of 170 to 240 basis points and 150 to 180 basis points that cannot be explained by the fundamental financial and economic data. Countries like Germany show the reverse phenomenon. These excess yield spreads are due to a loss of investor's confidence in excess of market data and fear of possible contagion effects. This investors' behavior closely matches Akerlof \& Shiller's (2009) theory of animal spirits in financial markets as well as Shiller's (2003) analysis on stock market returns in the last century.

\subsection{The impact of Eurobonds on interest rates}

In previous research, the impact of Eurobonds on interest rates has been highly controversial, both in terms of the channels through which Eurobonds affect interest rates as well as the expected effect. Following the classification of determinants from the previous section now in reverse order, three lines of research can be distinguished.

First, Favero and Missale (2011) argue that Eurobonds can prevent the propagation of crises. They analyze the role of financial markets as an insti- 
tution that controls fiscal discipline of countries and conclude that financial markets exert their control function only discontinuously and overreact to global risk variables. If this irrationality of the market lasts longer than a country can stay solvent and spreads to other countries with the bankruptcy of one country, the rationale for Eurobonds is to provide struggling countries with eased financing in a crisis and prevent contagion of crises.

Second, several authors have pointed to liquidity gains from Eurobonds that would lower interest rates. Delpla and von Weizsaecker (2011) estimate the global market for Eurobonds at $€ 5.6$ trillion. They predict this higher market size to increase liquidity to a point where yields for a Eurobond would be significantly lower than the weighted average of national bonds. However, they fail to provide reason why increased market size automatically leads greater liquidity and Carstensen et al. (2011) correctly point out that there need not be a direct link. Favero and Missale (2011) argue that in order to provide similar liquidity benefits as US bonds, Eurobonds would need 1 . the same credit quality as German Bunds and 2. a similar market size as the US bond market. They conclude that only safe and small issuers as Finland and Netherland would benefit from the increased liquidity of Eurbonds, whereas the benefits for countries like Germany would be marginal.

Third, it has been argued that via financial and economic fundamentals, Eurobonds will have an effect on interest rates. This line of literature does not expect a change in countries' fundamentals, but considers the interaction of fundamentals of participating countries when Eurobonds are introduced. Carstensen et al. (2011) in estimating additional costs to Germany with the introduction of Eurobonds argue that pooling sovereign debt in the European monetary union would yield an interest rate on Eurobonds equal to the weighted average interest rates of national bonds. They establish this claim by arguing that the joint guarantee of Eurobonds provides no benefit to investors, but fail to provide specific reasons for this statement. In contrast, Favero and Missale (2011) point out that interest rates of Eurobonds depend on the fiscal capacity of member states. To the extent that some countries have excess fiscal capacities, Eurobonds would yield lower than the weighted average interest rate of the national bonds. In their opinion, creditworthiness of Eurobonds depends on the ability to pay back debt, which is positively correlated to the fiscal capacity of member states. Consequently, the interest rate of Eurobonds would depend on fiscally strong countries. Grauwe and Moesen (2009) go further in arguing that even with more homogeneous countries, a Eurobond would decrease the probability of default of the network vis--vis individual countries. This idea is similarly found in Claessens, Mody, and Valle (2012), who argue that Eurobonds enable struggling countries better access to market funding and thereby greater chances 
to stay solvent in a crisis.

While these points are valid, no study provides a systematic analysis of why Eurobonds decrease the probability of default. Very rarely have Eurobonds been considered in the context of diversification effects for investors a concept known from financial theory. Only Hild et al. (2011) point out that Eurobonds could lead to diversification effects that create value for investors, as long as the assets of different countries are not perfectly correlated. However, they fail to consider that these diversification benefits can be replicated by investors in the absence of Eurobonds by just investing in all national bonds separately. This paper is the first to consider diversification effects of Eurobonds that are not replicable by investors and therefore create value for investors lowering both probability of default and nominal interest rates.

In the following section, I will lay down a theory of diversification and cross-subsidy that enables a country engaged in a fiscal network to default in less cases than in autarky.

\section{A Theory of Diversification and Cross-subsidy for Eurobonds}

Eurobonds are a form of risk-sharing between member states. Risk-sharing is constituted by the joint effect of cross-subsidy between states and diversification. Cross-subsidy refers to the characteristics of the joint guarantee of Eurobonds, that legally obliges fiscally stronger countries to support countries that are not able to honour their debt obligations. Diversification refers to the fact that given imperfect correlation between countries in the EMU, a negative shock in one country is likely to be offset by positive movements in other countries. Consequently, Eurobonds stabilize cash inflows of countries due to the joint effect of cross-subsidy and diversification. The cash inflow of a country is the primary surplus. Primary surplus refers to the difference between sovereign tax revenue and government expenditures. It is used to pay interest on sovereign debt.

Speaking in financial theory terms, investors in a country's bonds have a debt claim on the country's primary surplus. More stable cash flows evoked by Eurobonds lead to a higher probability that invested money is repaid, hence a lower probability of default and less expected losses. This effect is creating value for investors because it is not replicable by investing in countries seperately. Investors will therefore demand lower nominal interest rates than the weighted average interest rates of national bonds. The country itself has an equity claim on its primary surplus. Eurobonds reduce 
the volatility of the primary surplus. Consequently, the lower probability of default leads to a higher probability that a country serves its entire interest in a given year and are less able to accumulate the excess primary surplus as assets. Therefore, the equity claim and thus countries' remaining assets decline in value compared to individual bonds.

To understand why the benefits are not replicable by investors, I consider an investor holding sovereign bonds of $\mathrm{N}$ countries and an investor holding Eurobonds, thus joint debt issued and backed jointly by the $\mathrm{N}$ countries. These countries' economies are not perfectly correlated $(\varphi<1)$, so that there are idiosyncratic shocks that affect one country, but do not propagate to other countries economically. A shock is defined as an unforeseen adverse movement in a country's economy prompting it to default on its interest payments. For a country defaulting, there are no bankruptcy costs. Eurobonds do not create moral hazard problems.

If any country $C$ is hit by shock, this country will default on its interest payment. The investor holding national bonds will therefore have to bear a loss equivalent to shortcoming of a country's primary surplus, that is used to pay interest, and the nominal interest payment. For all other $N-1$ countries, the investor will earn the nominal interest rate $\mathrm{M}$. In contrast to the first investor, for the Eurobond investor the default of a country $\mathrm{C}$ does not automatically lead to a loss due to the cross-guarantee. Due to the idiosyncracy of the shock hitting country $\mathrm{C}$ and the imperfect correlation of economies, other countries are likely to be affected by positive movements in their economy, yielding a primary surplus in excess of their required debt payments. Due to the joint guarantee of Eurobonds, these countries are legally obliged and fiscally able to meet the interest payment of country C. Therefore, as long as the shortcoming of country C's primary surplus to nominal interest is lower than the sum of fiscal excess of the other $\mathrm{N}-1$ countries, the Eurobond will not default and investors receive their entire nominal interest. Even if the fiscal network defaults, the loss that investors have to bear is lower than the loss of the individual countries' investors as excess fiscal capacity of fiscally strong countries must legally be used to compensate investors for shortcoming of fiscally weak countries.

\title{
4 A Mathematical Model of Eurobonds
}

\subsection{Notation}

\author{
$\mathrm{N} \quad$ number of countries \\ $Y_{c, n} \quad$ gross domestic product of country c in year $\mathrm{n}$ \\ $S_{i} \quad$ primary surplus of country c
}




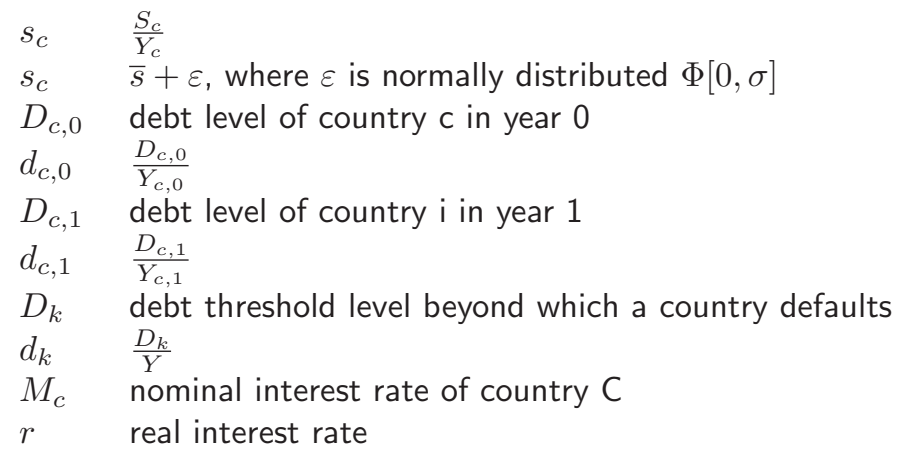

\subsection{Country in fiscal autarky}

I consider an environment of N symmetric and independent countries. Symmetry refers to the identity of the countries in terms of GDP, debt level, investors' attitude towards issued bonds as well as the tax revenue and expenditures. Independence refers to the autarky of each country in economic terms. Specifically, there are no trade and financial linkages so that shocks affecting any country are idiosyncratic in nature and do not cause a contagion effect in the other countries $(\varphi=0)$. A shock in this model is defined as an unforeseen adverse movement in primary surplus that prompts a country to default. Due to autarky between countries, shocks are idiosyncratic in nature. ${ }^{1}$

Each country has an amount of outstanding debt, $D_{c, 0}$, through a longrange inability to keep expenditures below or equal to tax revenues over the past. I express the debt level in percentage terms of the gross domestic product, $Y_{c}$, of each country, so that $d_{c, 0}=\frac{D_{c, 0}}{Y}$. For the entire model, GDP growth is assumed to be zero and therefore neglected.

Every year, a portion of the debt matures and the country needs to roll over the debt to guarantee liquidity. Research on sovereign bonds (Baglioni \& Cherubini, 2011) as well as recent experiences in Cyprus and Greece have shown that the inability to roll over debt is the main driver of a country's default, rather than failure to cover interest obligations with primary surpluses. To model this situation, Baglioni and Cherubini (2011) suggest a threshold debt level, $d_{k}$, beyond which investors lose faith in the country's ability to repay the debt and are unwilling to lend more money. This situation renders a debt roll-over impossible and necessitates default. In this

\footnotetext{
${ }^{1}$ For an entire enumeration of the assumptions underlying the model, please consult appendix 2
} 
paper, I adopt this proposal and define a threshold debt level, $d_{k}$. A country will not default as long as $d_{c, t} \leq d_{k}$. I assume that each country is already operating at its threshold level, so that $d_{0}=d_{k}$.

This model considers one country $C$ in year 0 , where $d_{c, 0}=d_{k}$. The country will not default in year 1 as long as $d_{c, 1} \leq d_{k}$. Over the course of the year, country $C$ has to pay interest on its outstanding debt at the level $M_{c} d_{c, 0}$, where $M_{c}$ denotes the nominal interest rate of country $\mathrm{C}$ and is for now assumed to be exogenously determined and stable across the fiscal network structure. Country $\mathrm{C}$ meets these interest obligations as well as finances government expenditures and purchases with earned tax revenues. Following Gaertner (2009), the difference between tax revenues and government expenditures constitutes a country's primary surplus $S_{c}$ or $s_{c}$ in relative terms. This primary surplus is designed to cover interest payments and is subject to fluctuations due to both tax revenue and expenditure volatility. I assume that the primary surplus is normally distributed with a mean $\bar{s}_{c}$ and a volatility of $\sigma_{c}$, where $\bar{s}>M_{c} d_{c, 0}$. This latter fact ensures that the probability of default is below 0.5 and makes the model more realistic, as Hild et al. (2011) report the implied default probability in European Monetary Union in a range between $0.00 \%$ and $14.63 \%$. The combination of positive debt level and positive primary surplus is usually observed in countries with low economic growth (Gaertner, 2009), which is compatible with both the assumption of zero GDP growth and the general notion of increased default risk. Defaulting countries generally exhibit low economic growth preceding their default (economist, 2011). The model is also applicable for countries exhibiting positive GDP growth and negative excess primary surplus over interest payment. Such a country's fiscal position can be transformed into one with no GDP growth and positive primary surplus, as indifference curves for these two variables have a negative slope, meaning that strong economic growth is comparable to excess primary surplus (Baglioni \& Cherubini, 2011).

The relation between the original debt level at $t=0$, the interest obligation, the primary surplus and the debt level at $\mathrm{t}=1$ is given by

$$
d_{c, 0}+M_{c} d_{c, 0}-s_{c}=d_{c, 1}
$$

In order to not default, country $C$ needs to ensure that $d_{1} \leq d_{k}$ at $\mathrm{t}=1$, so that

$$
d_{c, 0}+M_{c} d_{c, 0}-s_{c} \leq d_{k}
$$

Knowing that country $\mathrm{C}$ is already operating at its threshold level $d_{k}, d_{0}$ can be substituted by $d_{k}$ and equation (2) changes to

$$
M_{c} d_{c, 0}-s_{c} \leq 0
$$


Therefore, country $\mathrm{c}$ in year 1

$$
\begin{array}{ll}
\text { does not default if } & M_{c} d_{c, 0} \leq s_{c} \\
\text { and defaults if } & M_{c} d_{c, 0}>s_{i}
\end{array}
$$

Following Baglioni \& Cherubini (2011), the distance to default of country C is determined by the interest payment, the primary surplus as well as primary surplus volatility

$$
D D(t=1)=\frac{M_{c} d_{c, 0}-s_{c}}{\sigma_{c}}
$$

Correspondingly, the probability to default is given by

$$
\begin{aligned}
P(\text { default }) & =P\left(\frac{M_{c} d_{c, 0}-s_{c}}{\sigma_{c}}>0\right) \\
& =\Phi\left(\frac{M_{c} d_{c, 0}-\bar{s}}{\sigma_{c}}\right)
\end{aligned}
$$

In case the risk of default substantiates and the country is not able to rollover its debt, investors in sovereign bonds of country $\mathrm{C}$ experience a loss. In this model, I assume that the general principal is collatoralized so that investors at most lose the nominal interest at $t=1$. No liquidiation and bankruptcy costs are assumed in this preliminary analysis, thus the loss as a ratio over the interest is

$$
\text { for all } s_{c} \in \mathbf{R} \leq M_{c} d_{c, 0}: \quad L G D=1-\frac{s_{c}}{M_{c} d_{c, 0}}
$$

Combining (5) and (6) into a general expression for the probability and loss given default that the investor is exposed to yields

$$
\text { ExpectedLoss }=\int_{0}^{M_{c} d_{c, 0}} \Phi\left(\frac{s_{c}-\bar{s}_{c}}{\sigma_{c}}\right)\left(1-\frac{s_{c}}{M_{c} d_{c, 0}}\right)
$$

for all $s_{c} \in \mathbf{R} \leq M_{c} d_{c, 0}$.

\subsection{Country involved in fiscal network}

The preceding analysis assumed each country to issue its debt, pay interest and receive tax revenue independent of the other N-1 countries. In the following, I consider the effect of joint sovereign bonds of all $\mathrm{N}$ countries on the probability of default and the expected loss for investors. Following Favero and Missale (2011), I define joint sovereign bonds as bonds that are issued by an independent debt agency and represent claims on the pool of debt of all countries. These bonds are jointly backed by all countries. Consequently, the probability of default on an invidividual country c engaged in 
a fiscal network is equivalent to the probability of default of the entire fiscal network. As in the first scenario, countries are identical and independent economically $(\varphi=0)$. Consequently, their primary surpluses remain independent and shocks idiosyncratic. The only connection between countries is their fiscal network.

To model this situation, I take the perspective on an invidividual country. Except for the joint issuance of bonds, all other assumptions of the preceding analysis are held constant. Moreover, I assume that the joint bonds are structured in a way to prevent moral hazard. The issuance of joint bonds on the network level corresponds to a situation on a country level, where each country $C_{N}$ holds an equivalent share $\alpha$ of each country's debt and primary surplus including its own. Due to country's symmetry, $\alpha=\frac{1}{N}$. This situation is known as a complete interaction pattern (Cabrales, Gottardi, \& Vega-Redondo, 2013). When considering the impact of shocks on the network, it is easy to see why this exchange of assets effectively models the issuance of joint bonds on a macro-level. With joint bonds, any shock in country c does not disproportionally impact this country's probability of default compared to default probability of other countries because these other countries are legally obliged by the joint guarantee to financially support the affected country. This principle is known as cross-subsidization (Baglioni \& Cherubini, 2011). Thus, there is either a default of the entire network or none. The same is true for the model, in which each country holds an equal share $\alpha$ of country C's debt and surplusses. A shock in C also affects all countries equally. Matrix $A$ describes the situation resulting from the exchange of primary surplus.

$$
\begin{aligned}
& C_{1} \\
& C_{1} \\
& C_{2} \\
& \vdots \\
& C_{N}
\end{aligned}\left(\begin{array}{cccc}
\alpha_{11} & \alpha_{12} & \ldots & C_{N} \\
\alpha_{21} & \alpha_{22} & \ldots & \alpha_{1 N} \\
\vdots & \vdots & \ddots & \vdots \\
\alpha_{N 1} & \alpha_{N 2} & \ldots & \alpha_{N N}
\end{array}\right)
$$

Each country pays the same interest $M_{\text {network }}\left(\left(\alpha_{11} d_{c_{1}, 0}+\sum_{i=2}^{N} \alpha_{1 i} d_{c_{i}, 0}\right)\right.$, where $M_{\text {network }}$ denotes the nominal interest rate of the joint bonds and is assumed to be exogenously determined and equal to $M_{c_{1}} \mathrm{I}$ introduced for a country in fiscal autarky. I consider the same country $C=C_{1}$ as before after it has exchanged its assets. In order to not default at $\mathrm{t}=1$, it must be true

$$
\begin{aligned}
d_{c, 0}+M_{\text {network }} d_{c, 0}-s_{c} & \leq d_{k} \\
\left(1+M_{\text {network }}\right)\left(\alpha_{11} d_{c_{1}, 0}+\sum_{i=2}^{N} \alpha_{1 i} d_{c_{i}, 0}\right) & \leq d_{k}
\end{aligned}
$$




$$
d_{c, 0}=\alpha_{11} d_{c_{1}, 0}+\sum_{i=2}^{N} \alpha_{1 i} d_{c_{i}, 0} \quad \text { and } \quad s_{c}=\alpha_{11} s_{c_{1}}+\sum_{i=2}^{N} \alpha_{1 i} * s_{c_{i}}
$$

All countries are symmetric in terms of GDP and debt level and as all countries are already operating at their threshold level $d_{k}$, thus

$$
\alpha_{11} d_{c_{1}, 0}+\sum_{i=2}^{N} \alpha_{1 i} d_{c_{i}, 0}=d_{c_{1}, 0}=d_{k}
$$

It follows, that in year 1 , country 1

$$
\begin{array}{ll}
\text { does not default if } & M_{\text {network }} d_{c_{1}, 0} \leq \alpha_{11} s_{c_{1}}+\sum_{i=2}^{N} \alpha_{1 i} s_{c_{i}} \\
\text { and defaults if } & M_{\text {network }} d_{c_{1}, 0}>\alpha_{11} s_{c_{1}}+\sum_{i=2}^{N} \alpha_{1 i} s_{c_{i}}
\end{array}
$$

There are two kinds of shocks that can hit an individual country small and big shocks. Small shocks refer to fluctuations in surpluses which cause primary surpluses to be slightly below the required interest payment, whereas big shocks refer to significant negative deviations from the average primary surplus and cause a major shortfall of primary surplus to interest payments $M_{\text {network }} d_{c_{1}, 0}$. To allow for the normal distribution of $s_{c}$, I introduce a threshold level $\omega^{2}$, which marks the difference between small and big shocks. Specifically, for $M_{\text {network }} d_{c_{1}, 0}>s_{c_{1}} \geq \omega$, a shock is classified as small and for $s_{c_{1}}<\omega$, a shock as big. This threshold level is set in a way to ensure that if a small shocks hits one country, the network is able to insulate this shock and will not default, whereas a big shock in one individual country will cause the entire network to default. Moreover, the network of country will default, if two or more countries incur small shocks simultaneously in a magnitude that cannot be compensated by other countries. I use $p_{n}$ to denote the probability that the network defaults given simultaneous small shocks in $\mathrm{n}$ countries.

In mathematical terms, this implies

for small shocks ${ }^{3}$ : $\quad M_{\text {network }} d_{c_{1}, 0} \leq \alpha_{11} s_{c_{1}}$ (small shock) $+\sum_{i=2}^{N} \alpha_{1 i} s_{c_{i}}$

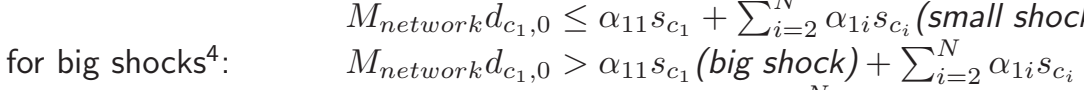

$$
M_{\text {network }} d_{c_{1}, 0}>\alpha_{11} * s_{c_{1}}+\sum_{i=2}^{N} \alpha_{1 i} s_{c_{i}} \text { (big shock) }
$$

for simultaneous small shocks with $p_{n}$ :

\footnotetext{
${ }^{2}$ in case of country symmetry $\omega$ can be approximated by $\bar{s}_{c_{1}}+M_{\text {network }} N-\bar{s}_{c_{1}} N$
} 
$M_{\text {network }} d_{c_{1}, 0}>\alpha_{11} s_{c_{1}}$ (small shock) $+\sum_{i=2}^{N} \alpha_{1 i} s_{c_{i}}$ ( $n-1$ small shocks)

$M_{\text {network }} d_{c_{1}, 0}>\alpha_{11} s_{c_{1}}+\sum_{i=2}^{N} \alpha_{1 i} s_{c_{i}}$ (n small shocks)

for simultaneous small shocks with $1-p_{n}$ :

$M_{\text {network }} d_{c_{1}, 0} \leq \alpha_{11} s_{c_{1}}$ (small shock) $+\sum_{i=2}^{N} \alpha_{1 i} s_{c_{i}}$ (n-1 small shocks)

$M_{\text {network }} d_{c_{1}, 0} \leq \alpha_{11} s_{c_{1}}+\sum_{i=2}^{N} \alpha_{1 i} s_{c_{i}}$ (n small shocks)

The probability of a small and big shock in a given country $C_{1}$ is

small shock: $\quad P\left(M_{c_{1}} d_{c_{1}, 0}>s_{c_{1}} \geq \omega\right)=\Phi\left(\frac{M_{c_{1}} d_{c_{1}, 0}-\bar{s}_{c_{1}}}{\sigma_{c_{1}}}\right)-\Phi\left(\frac{\omega-\bar{s}_{c_{1}}}{\sigma_{c_{1}}}\right)$

big shock: $\quad P\left(\omega>s_{c_{1}}\right)=\quad \Phi\left(\frac{\omega-\bar{s}_{c_{1}}}{\sigma_{c_{1}}}\right)$

Moreover, the probability $p_{n}$ of the entire network to default given $\mathrm{n}$ simultaneous shocks is an increasing function with the number of countries experiencing a small shock $\mathrm{n}$ and a decreasing function with the distance of $M_{\text {network }} d_{c_{1}, 0}$ and $s_{c_{1}}$. I therefore approximate $p_{n}$ by

$$
p_{n} \cong g\left(\frac{1}{d}\right)^{n} \frac{n}{N}
$$

where $g$ represents a constant multiplier and $d$ is a distance measure between $M_{\text {network }} d_{c_{1}, 0}$ and $s_{c_{1}}{ }^{5}$

Following Cabrales et al. (2013), I make the following assumption considering the nature of these shocks, which is increasingly reasonable with lower probability of default of a single country and increasing $\mathrm{N}$ :

$$
\Phi(\text { smallshock })>N \Phi(\text { bigshock })+\sum_{n=2}^{N} p_{n} \Phi(\text { nsmallshocks })
$$

Individual countries default with both small and big shocks. Network countries only default due to large shocks and simultaneous shocks, so that the probability of default for each type of country is

individual country: $\quad P\left(M_{c_{1}} d_{c_{1}, 0}>s_{c_{1}} \geq \omega\right)+P\left(\omega>s_{c_{1}}\right)$ network country: $\quad N P\left(\omega>s_{c_{1}}\right)+\sum_{n=2}^{N} p_{n} \Phi($ nshocks $)$

From (11) and because $N P\left(\omega>s_{c_{1}}\right)>0$, it follows that $P\left(M_{c_{1}} d_{c_{1}, 0}>s_{c_{1}} \geq \omega\right)+P\left(\omega>s_{c_{1}}\right)>N P\left(\omega>s_{c_{1}}\right)+\sum_{n=2}^{N} p_{n} \Phi($ nshocks $)$

\footnotetext{
${ }^{5} \mathrm{~d}$ can be approximated by $\frac{\bar{s}_{c_{1}}}{M_{\text {network }} d_{c_{1}, 0}}$
} 
Consequently, the probability of default is lower for country $C$ if it exchanges assets with other countries than if it is autarky. This finding closely matches Cabrales, Gottardi \& Vega-Redondo (2013), who argue in the case of private companies that due to lower probability of default, firm[s] will always want to display some links to others.

Next to the probability of default, it is also evident that given a default of an entire network, the loss to investors in comparable in magnitude, as long as

$$
L G D_{\text {individual }}{ }^{6}=1-\frac{s_{c_{1}}}{M_{c_{1}} d_{c_{1}, 0}} \cong 1-\frac{\alpha_{11} s_{c_{1}}+\sum_{i=2}^{N} \alpha_{1 i} s_{c_{i}}}{M_{c} d_{c, 0}}={ }^{7} L G D_{\text {network }}
$$

Therefore, given the assumptions it is not the country that is primarily benefiting from the exchange of debt, but rather investors that experience less losses on the nominal interest rate due to a lower probability of default.

\subsection{Transfer of assets}

The previous analysis has demonstrated that exchanging debt as a means of pooling sovereign debt reduces the probability of default and therefore the expected losses of investors of any country C. The situation of country C after interest payments have been made in year 1 has so far been excluded. Without default in year 1 , country $C$ accumulates the difference between primary surplus and interest payment as assets, which will be denoted as $A_{c}$. It is natural to consider whether the lower probability of default caused by pooling debt has any effect on the accumulated assets of country C.

Speaking in financial terms, countries have an equity claim on the surpluses after debt payments have been made. The equity claim is therefore equivalent to an option, whose value increases with the volatility of the surpluses. The exchange of assets laid down before reduces the probability of default by stabilizing primary surpluses. It is to be expected that this lower volatility reduces the equity claim of countries. The following part will mathematically analyze the impact of this stabilization on the assets remaining for the country after debt payments have been made.

The remaining assets $A c$ of country $C$ are the cumulative area below the normal distribution curve of $s_{c}$ times the difference of each $s_{c}$ to the interest payment. Following Baglioni and Cherubini (2011), the primary surplus distribution of an individual and network country can be modeled by

\footnotetext{
${ }^{6}$ for all $s_{c_{1}} \in \mathbf{R} \leq M_{c_{1}} d_{c_{1}, 0}$

${ }^{7}$ for all $\alpha_{11} s_{c_{1}}+\sum_{i=2}^{N} \alpha_{1 i} s_{c_{i}} \in \mathbf{R} \leq M_{c} d_{c, 0}$
} 


$$
\mu=\bar{s}_{\text {individual }}=\bar{s}_{\text {network }} \quad \text { and } \quad \sigma_{\text {network }}\left(\sigma_{n}\right)=\frac{\sigma_{\text {individual }}\left(\sigma_{i}\right)}{\sqrt{N}} .
$$

In the case that $s_{c_{1}} \geq M_{c_{1}} d_{c_{1}, 0}$, the remaining assets for the individual country are thus given by

$$
A_{\text {individual }}=\int_{M_{c_{1}} d_{c_{1}, 0}}^{\infty}\left(s_{c_{1}}-M_{c_{1}} d_{c_{1}, 0}\right) \frac{1}{\sigma_{i} \sqrt{2 \pi}} \mathrm{e}^{-\frac{\left(s_{c_{1}}-\bar{s}\right)^{2}}{2 \sigma_{i}^{2}}},
$$

remaining assets for the network country are

$$
A_{\text {network }}=\int_{M_{c_{1}} d_{c_{1}, 0}}^{\infty}\left(s_{c_{1}}-M_{c_{1}} d_{c_{1}, 0}\right) \frac{1}{\sigma_{n} \sqrt{2 \pi}} \mathrm{e}^{-\frac{\left(s_{c_{1}}-\bar{s}_{c_{1}}\right)^{2}}{2 \sigma_{n}^{2}}},
$$

and replacing $\sigma_{\text {network }}$ with $\frac{\sigma_{\text {individual }}}{\sqrt{N}}$ yields

$$
A_{\text {network }}=\int_{M_{c_{1}} d_{c_{1}, 0}}^{\infty}\left(s_{c_{1}}-M_{c_{1}} d_{c_{1}, 0}\right) \frac{\sqrt{N}}{\sigma_{i} \sqrt{2 \pi}} \mathrm{e}^{-\sqrt{N} \frac{\left(s_{c_{1}}-\bar{s}_{c_{1}}\right)^{2}}{2 \sigma_{i}^{2}}} .
$$

Whenever we have $s_{c_{1}}<M_{c_{1}} d_{c_{1}, 0}$, then the above three quantities equal 0 .

In this model, it is assumed that the interest rate, both $M_{\text {network }}$ and $M_{\text {individual }}$ are exogenously determined ex-ante and are not impacted by the exchange of debt. With $M_{\text {network }} \cong M_{\text {individual, }}$, simulation will show that $A_{\text {individual }}$ is strictly bigger than $A_{\text {network }}$ so that a country in a network will not accumulate as many assets as an individual country. In fact, simulation will show that the lower probability of default and the associated benefits for investors that I addressed earlier are exactly offset by a lower amount of accumulated assets in a risk-neutral world. This insight makes sense in that there is no value created by lower probability of default in the absence of risk aversion and bankruptcy costs.

\subsection{Endogenous interest rates}

Heretofore, it was assumed that interest rates are determined exogenously. Thus, investors required a fixed nominal interest rate ex-ante and the interest rates were not affected by the exchange of assets ex-post. However, this assumption is not realistic in the case of Eurobonds, where new joint bonds are successively issued and investors determine nominal interest rates knowledgable about the factual exchange of assets and debt. This section 
addresses how the findings gained before change with endogenous interest rates.

It is assumed that interest rates are solely determined by fundamentals and no liquidity premium is required by investors. Extending Hull et al.'s (2012) model about interest rates, the nominal interest rate of country C demanded by investors in sovereign bonds depends on the real interest rate, the probability of default and the loss given default as a percentage of the interest payment

$$
M_{c_{1}}=\frac{r}{1-p L}
$$

Hull et al.'s (2012) expression is based on risk-neutrality of investors, as no risk premia are offered to investors investing into sovereign bonds of country $\mathrm{C}$ to compensate for the risk of default. However, this expression also applies in this model, even if we assume risk-averse investors. Earlier on, I stated that primary surplus fluctuations which are the origin for default risk are idiosyncratic in nature. Therefore, they can be diversified away by investors and are a mere cost and no risk for investors. Thus, as long as the primary surplus fluctuations analyzed in this model are independent of each other, risk-neutrality is not a necessary condition for this model to hold.

In section 4.2 and 4.3 , I found expression for the probability of default and loss given default for a particular individual country $C$. Replacing $p$ and $L$ in (13) with the formulas developed in (5) and (6), the nominal interest rate of country $C$ is found by

$$
M_{c_{1}}=\frac{r}{1-\int_{0}^{M_{c_{1}} d_{c_{1}, 0}} \Phi\left(\frac{M_{c_{1}} d_{c_{1}, 0}-\bar{s}_{c_{1}}}{\sigma_{c_{1}}}\right)\left(1-\frac{s_{c_{1}}}{M_{c_{1}} d_{c_{1}, 0}}\right)}
$$

It becomes evident that the interest rate $M_{c}$ is indeed rather endogenously determined in the system than exogenously as previously assumed, so that there is a reverse causal relationship between interest rates and the probability of default.

It thus remains to be seen which effect the exchange of debt of country $C$ with the other $\mathrm{N}-1$ countries has on its nominal interest rate, specifically how $M_{\text {individual }}$ compares to $M_{\text {network. }}$ In (11) and (12) I developed expressions for the probability of default and the loss given default for a network country compared to an individual country. Consequently, it must be true for the nominal interest rate that

$$
M_{\text {network }}<\frac{r}{1-\int_{0}^{M_{c_{1}} d_{c_{1}, 0}} \Phi\left(\frac{M_{c_{1}} d_{c_{1}, 0}-\bar{s}_{c_{1}}}{\sigma_{c_{1}}}\right)\left(1-\frac{s_{c_{1}}}{M_{c_{1}} d_{c_{1}, 0}}\right)}=M_{\text {individual }}
$$


Consequently, in a situation of endogenous interest rates, the exchange of debt leads to lower expected losses for investors so that lower nominal interest rates are demanded. That creates a direct benefit for country $C$ in terms of the remaining assets. When reconsidering the formulas for the remaining assets, it becomes apparent that there is an inverse relationship between the nominal interest rate and the accumulated assets, meaning that lower nominal interest rates after the exchange of assets increase the assets that country $C$ can accumulate in year 1 . This benefit is confronted by the finding in section 4.4 , which demonstrated that the exchange of assets reduces the amount of remaining assets.

Before simulating these situations, I will provide theoretical reasoning why these two effects should exactly cancel out. It is known that the sum of interest payments to investors and remaining assets is equal to the primary surpluses that country $C$ generates in year 1

$$
I P_{\text {investor }}+A_{c_{1}}=s_{c_{1}}
$$

The exchange of debt has no effect on the surplus of any country $C$, as long as the structure of joint bonds effectively prevents moral hazard problems and there are no bankruptcy costs. The expected interest payments to investors are also equal for network countries vis--vis individual countries. Surely, network countries offer investors the benefit of lower probability of default and associated lower expected loss, but also have lower nominal interest rate (see equation 15). There is no risk premium paid to investors for the idiosyncratic risk of surpluses, so investors determine nominal interest rates in such a way that given the probability of default and loss given default, they are able to earn the real interest $r$ in both the network and individual country. If the expected payments to investors differed, there would be arbitrage possibilities that drive nominal interest rate spreads of individual and network countries to a level, where real earned interest is the same. As both primary surplus and expected payments to investors are the same for network and individual countries, from (16) remaining assets must also be equal, so that there is no benefit for both investors and countries from exchanging assets for no bankruptcy costs and risk aversion. This finding closely matches Butler's (2008) argumentation regarding the theoretical implications of hedging ac company's operational and transaction exposure. 


\section{Simulation of Eurobonds}

\subsection{Methodology}

In the previous sections, I have argued that issuing joint bonds are a form of risk sharing for the involved countries as long as their economies are imperfectly correlated $(\varphi<1)$. Risk-sharing is constituted by the joint effect diversification and cross-subsidy. This effect stabilizes cash inflows for a country in a way not replicable for investor and reduces the probability of sovereign default. Investors having a debt claim on a country's primary surplus benefit from this effect, as they experience less losses. Countries have an equity claim on their primary surplus. In the absence of bankruptcy costs, joint bonds are disadvantageous for countries, as they reduce primary surplus volatility. Thus, countries engaged in joint bonds will accumulate less assets than countries with national bonds.

In the following, I will perform simulations to substantiate the results found in the mathematical model and test them against changes in the assumptions. In order to measure the effect of issuing joint bonds on investors' expected losses and countries' remaining assets, two key variables are introduced. The first variable, subsequently denoted Jlloss, is the ratio of expected losses incurred for investors in Joint bonds over the expected losses incurred for investors in Individual bonds issued by the same countries. $^{8}$ This variable is chosen instead of probability of default, because expected losses build the basis for determining nominal interest rates (Hull et al., 2012). The second variable, subsequently denoted Jlassets, is the ratio of the assets a country is able to accumulate with joint bonds over the remaining assets of a country with national bonds. Depending on the setting, I will consider the probability of default and the transfer of primary surplus between countries.

To measure the effect of joint bonds on these variables, I will perform a range of simulations systematically changing underlying assumptions ${ }^{9}$. First, I will estimate the basic model laid down in the previous section. All assumptions for the mathematical model also hold for this simulation. Moreover, I will test the outcome against changes in the number of involved countries. Second, I will estimate bankruptcy and liquidation costs both for investors and countries and simulate joint bonds. In the third simulation, I will make interest rates endogenous and consider the magnitude change from exogenous to endogenous interest rates. Fourth, I will extend the one-year

\footnotetext{
${ }^{8}$ mathematically $\mathbf{J l}$ loss $=\frac{E L_{\text {jointbonds }}}{E L_{\text {individualbonds }}}$ and Jlassets $=\frac{A_{\text {jointbonds }}}{A_{\text {individualbonds }}}$

${ }^{9}$ for an overview of the assumption changes in each respective simulation, please refer to the appendix
} 
model applied heretofore to a multi-year model and consider potential intertemporal diversification effects. The fifth and sixth model will encompass changes in the probability distribution and introduce correlation between countries' primary surpluses. Last, I will consider a network of heterogeneous countries differing in terms of Gross Domestic Product (GDP) and fiscal stability. In this part, I will also take a micro-perspective and consider the transfer of primary surplus between countries and its effect on the previous results.

Throughout the simulation, I will consider a network of $\mathrm{N}=3$ countries as the base case. Following Cabrales et al. (2013), this number is appropriate to measure network effects. Whenever not specified, the simulation is based on three countries, which are uncorrelated to each other economically and financially $(\varphi=0)$. Throughout the simulations as laid down in the mathematical model the interest payment as well as the debt level are assumed to be constant and can be determined ex-ante. There is no uncertainty involved with these variables. The changing variable is the primary surplus which is normally distributed around the mean primary surplus $\bar{s}$ with a standard deviation $\sigma_{s}$. The mean primary surplus and standard deviations are changed from simulation to simulation to account for a wide range of possible scenarios. Specifically, they are determined in a way that the probability of default of a given country $C$ ranges between $0.135 \%$ and $84.13 \%$. A default probability of $15.85 \%$ is the base case, which resembles the implied default probability of Greece (Hild et al., 2011). The assumed excess primary surplus and volatility also match Baglioni and Cherubini's (2011) estimates. This base case was selected in order to highlight the difference between a country in fiscal autarky and in a fiscal network as well as to demonstrate that the benefits from cross-subsidy and diversification are not exclusively accessible for fiscally strong countries. As in the mathematical model, default occurs as soon as primary surplus is below required interest payments in a given year. Primary surplus and standard deviation will be consistently expressed in terms of the interest payment.

\subsection{Basic Model}

In the following, I will present the main findings of these simulations along with section in which I connect the ideas to construct a comprehensive picture of the effects of Eurobonds on sovereign default probability and investors' losses. 


\subsubsection{Changing primary surplus mean and volatility}

Main finding 1 . The simulation supports the mathematical model. Investors of countries engaged in a fiscal network incur less losses, whereas countries are able accumulate less primary surplus as assets.

\subsubsection{Changing number of countries}

Main finding 2. Increasing the number of network countries is beneficial for investors in terms of losses and detrimental for the country in terms of accumulated assets.

\subsection{Basic Model accounting for bankruptcy costs}

Main finding 3. When accounting for bankruptcy costs, joint bonds are unambiguously desirable. They decrease costs for investors and increase remaining assets for countries.

\subsection{Basic Model with endogenous interest rates}

Main finding 4. Modeling using endogenous interest rates yields the same insights as with exogenous interest rates, only more amplified, both for without and with bankruptcy costs. Only Jlassets is constantly 1 for no bankruptcy costs as suggested in the mathematical model.

\subsection{Changing to a multi-year model}

Main finding 5. Changing from a one-year to a multi-year model changes the results neither qualitatively nor significantly quantitatively.

\subsection{Changing the primary surplus probability distribution}

Main finding 6. If there are rare, but serious uncorrelated disasters, the benefits from joint bonds persist, but there is an optimal network structure that minimizes the probability of default and that is different from infinity.

\subsection{Changing Correlation between countries}

Main finding 7. Higher correlation between countries' primary surpluses diminishes the effect of cross-subsidy and diversification. Nevertheless, significant benefits remain as long as countries are not perfectly correlated $(\varphi<1)$. 


\subsection{Basic Model with heterogeneous countries}

Main finding 8. Heterogeneity between countries does not significantly change previous findings on a macro-level. On a micro-level, fiscally strong countries have to consider whether the benefits of a fiscal networks outweigh the costs constituted by higher interest payments and transfer of assets in case of default.

\subsection{Connecting the Insights}

The previous simulations have performed extensive sensitivity analyses to the theory laid down in the mathematical model in terms of changing crucial assumptions. Generally, the theory's insights are robust against a range of assumptions and demonstrate the benefit associated with joint bonds on a macro-level. This section combines these insights to predict qualitatively the effect of Eurobonds on probability of default, investors' losses and countries' remaining assets in terms of diversification and cross-subsidy.

Research as presented in the individual simulation parts indicates that countries in the EMU are heterogeneous both in terms of size and fiscal stability. They are also not independent of each other in economic and financial terms. The correlation coefficient between EMU countries is estimated at $81 \%$ (Baglioni \& Cherubini, 2011). Moreover, primary surplus exhibits sizable negative shocks and interest rates on Eurobonds will be determined endogenously. Last, sovereign default is associated with significant bankruptcy costs that both investors and countries are exposed to.

When accounting for these differences, Eurobonds are beneficial for both countries and investors on a macro-level. They reduce sovereign default probability and thereby prevent bankruptcy costs. The endogenous interest rate determination will amplify this effect, whereas the correlation between countries' GDP diminishes it. Serious consideration has to be given to optimal network structure to ensure that rare, but serious shocks do not increase the probability of network default compared to an individual country. On a micro-level, fiscally stronger countries have to weigh the benefits of diversification and cross-subsidy against the two-fold costs of Eurobonds: 1 . Higher interest payments in normal times and 2. Transfer of assets in case of default.

\section{Limitations and Future Research}

This paper provides the first stringent analysis of Eurobonds effect on sovereign default probability, investors' losses and countries' remaining assets via di- 
versification and cross-subsidy. It also performs sensitivity analysis against the gained insights. Nevertheless, the simulation suffers from some important drawbacks that will need to be addressed by future research. First, the model is built on a simplified view of reality. The assumptions underlying the basic model were selected to clearly pinpoint the effect of Eurobonds. While the previous section combines the insights yielded in the simulation into a more realistic prediction, a comprehensive analysis is necessary on real-world effects of Eurobonds. Second, except for the endogenous determination of interest rates, the model is based on comparative statics. All variables are exogenously defined and the dynamic relationship among them neglected. In the light of the reality of sovereing bond spreads, this approach is not entirely appropriate (Gabrisch \& Orlowski, 2010). Third, this model assumes that fundamentals govern yield-spread differentials and that excessive yield spreads in crisis times prompt countries to default on sovereign debt. However, Favero and Missale (2011) point out that there are a other factors besides fundamentals such as liquidity and psychological contagion that determine yield spreads. It remains unclear which factor causes excessive yield spreads in crisis times with important implications for the validity and strength of the argument put forward in this paper.

Future research can address these drawbacks with the following steps. First, a thorough test is necessary on the reasonableness of the assumptions. This test should elaborate on the most realistic set of assumptions to use when simulating Eurobonds as well as incorporating feedback loops of variables to account for their dynamic nature. Second, future research will need to provide estimates for the variables identified in the model based on the set of assumptions deemed realistic. Third, a tentative estimate can be formulated on the effect that Eurobonds will have on interest rates via diversification and cross-subsidy. With these steps, the theoretical argument developed in this paper can add practical value to the Eurobonds debate and contribute to a more comprehensive consideration of benefits and drawbacks of common sovereign bonds in the European Monetary Union.

\section{Conclusion}

In recent years, several EMU member states have faced difficulties refinancing their sovereign debt due to excessive yield spreads on their national bonds. One of the dominant proposal in the political and economic debate about solutions are common bonds issued and backed jointly by EMU member states. These bonds became known as Eurobonds. Considerable debate has taken place on the effect that Eurobonds have on interest rates. This paper is the first to develop a theory that demonstrates diversification 
and cross-subsidy benefits associated with Eurobonds. I have argued that because Eurobonds are jointly backed by all EMU countries, the probability of sovereign default decreases for a country issuing Eurobonds vis--vis national bonds. In the very basic model assuming no bankruptcy costs and no economic correlation, this lower probability of default results in lower investor's losses, but decreases the primary surplus that countries are able to accumulate from excess primary surplus. The theory behind these results implies that Eurobonds are a form of risk-sharing stabilizing cash inflows used to pay debt holders. Investors in sovereign bonds have a debt claim and benefit from decreased primary surplus volatility, whereas the country with an equity claim on the primary surplus suffers from lower volatility. Following the basic mathematical model, I performed sensitivity simulations against changes in the assumptions. In a realistic consideration of EMU countries, there are significant bankruptcy costs, heterogeneity and correlation between countries, endogenous interest rates and not normally distributed primary surplus. When taking these factors into account, Eurobonds prevent bankruptcy costs due to lower default probability and are welfare-increasing for both investors and countries on a macro-level. This is the case as long as primary surplus shocks occur with such a frequency and magnitude that the number of EMU member states is optimal or at least reasonable in terms of fiscal network size. However, fiscally strong countries have to weigh the benefits of diversification and cross-subsidy against the two-fold costs of Eurobonds: 1 . Higher interest rates in normal times and 2. Transfer of primary surplus to countries at the brink of default. Policymakers need to ensure that the structure of Eurobonds does not result in a transfer union from fiscally strong to weak countries. Future research will need to make the theoretical argument put forward in this paper more realistic by identifying the appropriate set of assumptions and providing estimates for the variables in the model. Thereby, the theory of diversification and crosssubsidy adds practical value to the Eurobonds debate and contributes to a more comprehensive consideration of benefits and drawbacks of common sovereign bonds in the European Monetary Union. 


\section{References}

Akerlof, G. A., \& Shiller, R. J. (2009). Animal spirits - how human psychology drives the economy and why it matters for global capitalism. New Jersey: Princeton University Press.

Amira, K. (2004). Determinants of sovereign eurobonds yield spread. Journal of Business Finance \& Accounting, 31(5-6), 795-821.

Arghyrou, M. G., \& Chortareas, G. (2006, September). Current account imbalances and real exchange rates in the euro area (Cardiff Economics Working Papers No. E2006/23). Cardiff University, Cardiff Business School, Economics Section.

Baglioni, A., \& Cherubini, U. (2011). A theory of eurobonds. Working Papers, 1-22.

Barbosa, L., \& Costa, S. (2010). Determinants of sovereign bond yield spreads in the euro area in the context of the economic and financial crisis. Economic Bulletin and Financial Stability Report Articles, 1-38.

Barrios, S., Iversen, P., Lewandowska, M., \& Setzer, R. (2009, November). Determinants of intra-euro area government bond spreads during the financial crisis (European Economy - Economic Papers No. 388). Directorate General Economic and Monetary Affairs (DG ECFIN), European Commission.

Blanchard, O., \& Giavazzi, F. (2002). Current account deficits in the euro area: The end of the feldstein horioka puzzle? Brookings Papers on Economic Activity, 33(2), 147-210.

Blommestein, H. J., Derya, E. V., \& Flores, P. I. (2010). Oecd sovereign borrowing outlook no.3. OECD Journal: Financial Market Trends, 2010(2), 1-15.

Bosch, X. V., \& Verhelst, S. (2012, 06). A briefing on eurobonds. , 1-8.

Cabrales, A., Gottardi, P., \& Vega-Redondo, F. (2013). Risk-sharing and contagion in networks. Working paper, 1-47.

Carstensen, K., Berg, T. O., \& Sinn, H.-W. (2011, 09). What costs do eurobonds cause? [was kosten eurobonds?]. Ifo Schnelldienst, 64(17), 25-33.

Chinn, M., \& Frankel, J. (2005, August). Will the euro eventually surpass the dollar as leading international reserve currency? (NBER Working Papers No. 11510). National Bureau of Economic Research, Inc.

Claessens, S., Mody, A., \& Valle, S. (2012, July). Paths to eurobonds (IMF Working Papers No. 12/172). International Monetary Fund.

Cohen, M. (2012). Argentina's economic growth and recovery, 2001-2008: The economy in a time of default. Routledge.

Damodaran, A. (2013, January). Cost of capital by sector. Retrieved from 
http://pages.stern.nyu.edu/adamodar/NewHomePage/datafile/ wacc.html.htm

Datz, G. (2009). What life after default? time horizons and the outcome of the argentine debt restructuring deal. Review of International Political Economy, 16(3), 456-484.

Delpla, J., \& von Weizsaecker, J. (2011, March). Eurobonds: The blue bond concept and its implications (Policy Contributions No. 509). Bruegel.

De Paoli, B., \& Hoggarth, G. (2006). Costs of sovereign default. Bank of England Quarterly Bulletin, Fall.

Dewachter, H., lania, L., Lyrio, M., \& de Sola Perea, M. (2013). A macrofinancial analysis of the euro area sovereign bond market. Working Papers, 1-42.

Dwyer, J. G. P., \& Hafer, R. W. (1998). The federal government's budget surplus: Cause for celebration? Economic Review(Q 3), 42-51.

economist, T. (2011, 06). To default, or not to default? Retrieved from http://www.economist.com/blogs/dailychart/2011/06/ sovereign-defaults-and-gdp

Eichengreen, B., \& Portes, R. (1985). Debt and default in the 1930s: Causes and consequences (CEPR Discussion Papers No. 75). C.E.P.R. Discussion Papers.

Fagan, G., \& Gaspar, V. (2007, January). Adjusting to the euro (Working Paper Series No. 716). European Central Bank.

Favero, C. A., \& Missale, A. (2010). Eu public debt management and eurobonds (Tech. Rep.). Brussels.

Favero, C. A., \& Missale, A. (2011, November). Sovereign spreads in the euro area: Which prospects for a eurobond? (CEPR Discussion Papers No. 8637). C.E.P.R. Discussion Papers.

Gabrisch, H., \& Orlowski, L. T. (2010, November). Interest rate convergence in euro-candidate countries: Volatility dynamics of sovereign bond yields. Emerging Markets Finance and Trade, 46(6), 69-85.

Gaertner, M. (2009). Macroeconomics. third revised edition. Prentice Hall International.

Giordano, L., Linciano, N., \& Soccorso, P. (2012). The determinants of government yield spreads in the euro area. CONSOB Working Papers No. 71, 1-44.

Gopal, M., \& Pasche, M. (2012). Market-based eurobonds without crosssubsidisation (Global Financial Markets Working Paper Series No. 2012-37). Friedrich-Schiller-University Jena.

Grauwe, P. D., \& Moesen, W. (2009). Common euro bonds: Necessary, wise or to be avoided. Intereconomics - Review of European Economic Policy, 132-141. 
Hatchondo, J., Martinez, L., \& Sapriza, H. (2007). The economics of sovereign defaults. FRB Richmond Economic Quarterly, 93(2), 163187.

Herrmann, S., \& Jochem, A. (2005). Determinants of current account developments in the central and east european eu member states consequences for the enlargement of the euro area (Discussion Paper Series 1: Economic Studies Nos. 2005,32). Deutsche Bundesbank, Research Centre.

Hild, A., Herz, B., \& Bauer, C. (2011). Structured eurobonds. Wirtschaftswissenschaftliche Diskussionspapiere, 1-45.

Hull, J. C. (2011). Fundamentals of futures and options markets. New Jersey: Pearson Education.

Hull, J. C., Predescu, M., \& White, A. (2012). Bond prices, default probabilities and risk premiums. Journal of Credit Risk, 1-11.

la Dehesa, G. D. (2011). Eurobonds: Concepts and implications (Tech. Rep.). Brussels.

Lane, P. R. (2012, Summer). The european sovereign debt crisis. Journal of Economic Perspectives, 26(3), 49-68.

Milesi-Ferretti, G.-M., \& Tille, C. (2010, June). The great retrenchment: International capital flows during the global financial crisis (IHEID Working Papers No. 18-2010). Economics Section, The Graduate Institute of International Studies.

Muellbauer, J. (2011, October). Resolving the eurozone crisis: Time for conditional eurobonds. , 1-10.

OECD. (2012). Oecd economic outlook no 92 - oecd annual projections (Tech. Rep.). Author.

Prinz, A., \& Beck, H. (2012). Fighting debt explosion in the european sovereign debt crisis. Intereconomics, 47(3), 185-189.

Reinhart, C. M., \& Rogoff, K. S. (2010, March). From financial crash to debt crisis (NBER Working Papers No. 15795). National Bureau of Economic Research, Inc.

Shiller, R. J. (2003, Winter). From efficient markets theory to behavioral finance. Journal of Economic Perspectives, 17(1), 83-104.

Stiglitz, J. E. (2010, February). Risk and global economic architecture: Why full financial integration may be undesirable (NBER Working Papers No. 15718). National Bureau of Economic Research, Inc.

Sturzenegger, F., \& Zettelmeyer, J. (2006). Haircuts: Estimating investors losses in sovereign debt restructurings, 1998-2005 (Business School Working Papers No. 2006-02). Universidad Torcuato Di Tella.

Torgersen, C.-E. (2012). Eurobonds (Tech. Rep.). Harvard.

Yeyati, E. L., \& Panizza, U. (2011, January). The elusive costs of sovereign 
defaults. Journal of Development Economics, 94(1), 95-105.

Yue, V. Z. (2010, March). Sovereign default and debt renegotiation. Journal of International Economics, 80(2), 176-187. 